\title{
THE IMPACT OF SOCIAL SCIENCE EVIDENCE ON THE JUDGE: A PERSONAL COMMENT
}

\author{
J. Braxton Craven, Jr.*
}

We all do it: even the best of us overread opinions. From the first weeks of law school, iterated and reiterated through our professional lives, we have heard and understood that the opinion of an appellate court is to be read in its own fact context; but we remember a ringing phrase longer than we remember its factual setting. And so we respond to the opinion author's exhortation and hyperbole. Who can forget "neither black schools nor white schools, just schools," systems at once and to operate now and hereafter only unitary schools," 2 or "[f]urther delays will not be tolerated in this circuit." 3 But how many of us remember that the first phrase was written in a rural fact setting presenting none of the insoluble integration problems encountered in the cities, and that the second and third were directed toward recalcitrant school boards that had stubbornly set their face against compliance with new constitutional doctrine? The author of such inspirational rubric is sometimes astonished at overcompliance by those who read it out of context.

John Mull never tired of telling me in my first ten years of law practice to "salt down the facts." 4 Facts are the premises of a syllogism to invoke a legal doctrine. I once knew another distinguished lawyer whose respect for the facts was so great that he commonly drew the judgment he sought before drafting his complaint to make sure he pleaded enough facts. Implicit in the Supreme Court's doctrine of "constitutional facts" is its recognition that it can write law all day long to no avail unless its abstractions can be brought to bear upon the conduct of human affairs.

\footnotetext{
* Judge, United States Court of Appeals for the Fourth Circuit. [Judge Craven is the author of Bradley v. School Bd. of City of Richmond, 462 F.2d 1058 (4th Cir. 1972), aff'd by an equally divided Court, 412 U.S. 92 (1973). Editors' Note.]

1. Green v. County School Bd., 391 U.S. 430, 442 (1968).

2. Alexander v. Holmes County Bd. of Educ., 396 U.S. 19, 20 (1969).

3. Nesbit v. Statesville City Bd. of Educ., 418 F.2d 1040, 1042 (4th Cir. 1969).

4. The late John M. Mull, Esquire, of Morganton, North Carolina, was forty-four years my senior and my law partner.

5. Legislative facts are those which the court uses to develop law or policy. 2 K. Davis, Administrative Law Treatise $\$ 15.03$ (1958). Constitutional facts are legislative facts that bear on the constitutionality of governmental practices. P. Brest, Process of Constitutional Decision-Making (1974). For an example of a case turning on constitutional facts, see Furman v. Georgia, 408 U.S. 238 (1972).
} 
A facetious complaint among lawyers is that they sometimes have trouble identifying the case they tried below as the one being described in the appellate opinion. That this is even partly true illustrates what everyone knows: that judges much more often disagree on the facts or the proper inferences to be drawn from the facts than on the law.

To give a simplistic answer to a difficult question: the role that the social sciences ought to play in the judicial decision-making process is, of course, the same as the role of any other science, whether medical, electronic, or atomic. In short, all sources of human information and knowledge properly contribute to the determination of the facts.

From Lochner v. New York ${ }^{6}$ to Roe v. Wade ${ }^{7}$ and Doe v. Bolton, ${ }^{8}$ there has seemingly been little change in the doctrine of substantive due process. But the facts have changed, or if they have not changed, the Court's awareness of the facts has changed-which is to the same effect. From Nebbia $v$. New York ${ }^{9}$ until the present, the Court has become increasingly suspicious of its own expertise in economics and increasingly assured of its own competence in the social science areas. And so there has been less and less protection of contract and property interests and more and more protection of personal liberty, including the discernment of rights that are not apparent on the face of the Constitution. ${ }^{10}$ The Brandeis brief was an innovation in Muller $v$. Oregon, ${ }^{11}$ but is now standard operating procedure in equal employment, ecology, and major school desegregation cases. The problem is not whether to use the social sciences, or whether it is proper to do so, but how to persuade the courts of the truth of the ultimate facts asserted. Courts are comfortable with evidentiary facts-how fast the car was being driven-and are uncomfortable with conclusory facts-what caused the tire to blow out. One of the few reasons for wanting to retain trial by jury in civil cases is that difficult questions such as negligence can be left to the jury. Aided by the failure to sustain the burden of proof standard, there is no question too hard for the jury to answer. It is not surprising, therefore, that the courts are uneasy in the presence of the ultimate facts or conclusions of the social sciences because we have many times consumed large quantities of social science-from Dred Scott ${ }^{12}$ to Lochner ${ }^{13}$-only to have to regurgitate it.

\footnotetext{
6. 198 U.S. $45(1905)$.

7. 410 U.S. $113(1973)$.

8. 410 U.S. $179(1973)$.

9. 291 U.S. 502 (1934).

10. See, e.g. Griswold v. Connecticut, 381 U.S. 479 (1965).

11. 208 U.S. 412 (1908). Louis Brandeis filed a 113-page brief supporting Oregon's maximum hour law for women, drawing upon foreign, federal, and state studies concerning women's reactions to contemporary working conditions. The views of American, French, and German doctors were cited by Brandeis as evidence that women could not tolerate the same working hours as did men. Brief for Defendant in Error, Muller v. Oregon, $i d$.

12. Scoll v. Sandford, 60 U.S. (19 How.) 393 (1854).

13. Lochner v. New York. 198 U.S. 45 (1905).
} 
In the year 1856, William A. Smith, Doctor of Divinity and President of Randolph Macon College, entered in the office of the clerk of the district court for the middle district of Tennessee, a copy of his lectures that had been delivered to the classes in moral science at Randolph Macon College for many years. The lectures were entitled The Philosophy and Practice of Slavery and were published by Stephenson \& Owen, Nashville, Tennessee, in 1857, the same year that $S$ cott $v$. Sandford ${ }^{14}$ was decided by the United States Supreme Court. I should think that Dr. Smith would have cheerfully admitted to being a social scientist, and a distinguished one at that. The burden of his message to his contemporaries, as stated in the first chapter, is that domestic slavery is not sinful and that slavery, per se, is right; "or that the great abstract principle of slavery is right, because it is a fundamental principle of the social state; and that domestic slavery, as an institution, is fully justified by the condition and circumstances (essential and relative) of the African race in this country, and therefore equally right." 15

Chief Justice Taney's opinion does not mention Dr. Smith's book, but it is easy to suppose that he may have read it or others like it. In deciding whether Dred Scott was a citizen and entitled to bring a diversity of citizenship action in a federal court, the Chief Justice displayed great interest in "the state of public opinion in relation to that unfortunate race, which prevailed in the civilized and enlightened portions of the world at the time ... when the Constitution of the United States was framed and adopted." 16 The factual context within which the Court decided the case was, with respect to the status of the Negro, stated to be as follows: ${ }^{17}$

They had for more than a century before been regarded as beings of an inferior order, and altogether unfit to associate with the white race, either in social or political relations; and so far inferior, that they had no rights which the white man was bound to respect; and that the negro might justly and lawfully be reduced to slavery for his benefit. He was bought and sold, and treated as an ordinary article of merchandise and traffic, whenever a profit could be made by it. This opinion was at that time fixed and universal in the civilized portion of the white race. It was regarded as an axiom in morals as well as in politics, which no one thought of disputing, or supposed to be open to dispute; and men in every grade and position in society daily and habitually acted upon it in their private pursuits, as well as in matters of public concern, without doubting for a moment the correctness of this opinion.

Some forty years later Mr. Justice Brown concluded that the fourteenth amendment "could not have been intended to abolish distinctions based upon color." ${ }^{8}$ Writing for the Court in Plessy v. Ferguson, ${ }^{19}$ he depended heavily

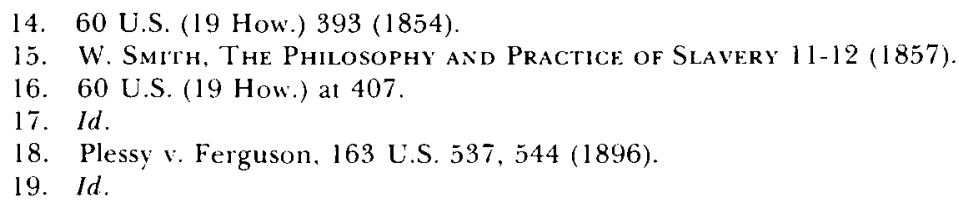


upon consensus of public opinion with respect to race relations. He nailed down apartheid for his time by reference to the established usages, customs, and traditions of the people. ${ }^{20}$ Rather happily he concluded that "if one race be inferior to the other socially, the Constitution of the United States cannot put them upon the same plane." ${ }^{21}$ Dr. Smith would have agreed.

But by 1954 the Court was no longer reading Dr. Smith nor was it impressed by "the extent of psychological knowledge at the time of Plessy $v$. Ferguson." ${ }^{22}$ In Brown v. Board of Education, ${ }^{23}$ Chief Justice Warren and members of his Court may have reached a new high in judicial intellectual honesty. Gone is Mr. Justice Brown's sophistry that if enforced separation of the races "stamps the colored race with a badge of inferiority" it "is solely because the colored race chooses to put that construction upon it." 24 Supported only by a compilation of psychological and sociological studies of the status of the Negro in America, the Court flatly concluded that "separate educational facilities are inherently unequal." 25 The decision was not addressed to lawyers but to the people. Although startling at the time, the decision now rests upon a bedrock of public opinion that school assignments and other legal distinctions based upon race are denigrating to the minority ethnic group and are simply unfair. After twenty years of more or less successful attempts to implement Brown, I think it can be said that there is a general consensus that enforced separation of any race or group from the mainstream of society stigmatizes those against whom such coercive laws are directed. Beyond that there is little agreement and much uncertainty.

Many an inferior court, overreading Green v. County School Board of New Kent County, ${ }^{26}$ Davis v. Board of School Commissioners of Mobile County, ${ }^{27}$ and Swann v. Charlotte-Mecklenburg Board of Education, ${ }^{28}$ thought that the Court's dogma mandated racial balance ${ }^{29}$ despite occasional cryptic disclaimers. ${ }^{30}$ What the

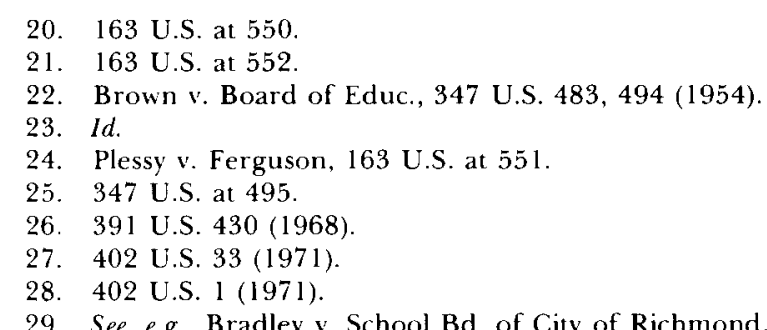

29. See, e.g., Bradley v. School Bd. of City of Richmond, 325 F. Supp. 828 (E.D. Va. 1971). In Bradley, the district court approved the adoption of a Richmond metropolitan school plan where 97 per cent of the black students in the metropolitan area (the three jurisdictions included in the metropolitan area being the City of Richmond, Chesterfield County, and Henrico County) would attend schools with racial compositions in the range of 20-40 per cent black. The Fourth Circuit reversed on the grounds that where each of the districts had achieved unitary school systems, it was not within the district court's authority to order the consolidation of three separate political subdivisions of the Commonwealth of Virginia. 462 F.2d 1058, 1069 (4th Cir. 1972), aff'd by an equally divided Court, 412 U.S. 92 (1973).

30. In Swann, the district court ordered the school system to establish a 71 to 29 per cent ratio of whites to blacks in the city's schools. On appeal the Supreme Court clarified its position on racial 
Court said in Swann seemed to some not nearly so important as what it did in Davis. ${ }^{31}$ One did not have to be stupid to have thought in 1970 that every class in every grade in every school in every zone within a given district must be integrated, and that integration meant the maximum possible amount of desegregation or mixing of the races. There was a time when members of my court were so concerned with the attainment of mixing that we even considered minimizing the apparent danger of white flight. I debated the question with my late dear friend, Judge Sobeloff, in Brunson v. Board of Trustees of School District No. $1,^{32}$ and until Milliken v. Bradley ${ }^{33}$ was decided on July 25, 1974, I would have thought it a standoff. Brunson got us into sociology over our heads. After acknowledging my own ignorance of sociology and educational theory, I quoted Dr. Thomas F. Pettigrew of Harvard University that the optimum mix was 30 per cent black to 70 per cent white. ${ }^{34}$ The same sociological input must have influenced Judge McMillan in Swann, for he suggested that it would be desirable if the school board assigned students on the basis of a $71 / 29$ ratio of white to black students. ${ }^{35}$

In September, 1969, there were 2,408 black students and 256 white stu-

balance. "[T]he use made of mathematical ratios was no more than a starting point in the process of shaping, rather than an inflexible requirement." 402 U.S. at 25. "If we were to read the holding of the district court to require, as a matter of substantive constitutional right, any particular degree of racial balance or mixing, that approach would be disapproved and we would be obliged to reverse. The constitutional command to desegregate schools does not mean that every school in every community must always reflect the racial composition of the school system as a whole." 402 U.S. at 24 .

31. The Fifth Circuit, in Davis, approved a desegregation plan which used a major north-south highway as a dividing line between two school zones. On the east side of the highway lived 94 per cent of the metropolitan area's Negro students. About 88 per cent of the students on the west side of the highway were white. The Supreme Court reversed and remanded on the basis that every effort to achieve the greatest possible degree of desegregation must be explored, including the possibility of the use of bus transportation and split zoning. While not attacking the racial imbalance itself, the Court did imply that a major highway was not to be a barrier to desegregation. See Davis v. Commissioners of Mobile County, 402 U.S. 33 (1971).

32. 429 F.2d 820 (4th Cir, 1970). Because of the small number of whites in Clarendon County, South Carolina, it was feared that unyielding compliance to arithmetical formulas to achieve racial balance would drive whites to the parochial schools. "It will be ironic, and contrary to the spirit of Brown v. Board of Education of Topeka, [citations omitted] if the result of the application of the Brown constitutional principle in this case is simply to accomplish an all-black school system." 429 F.2d at 822 (Craven, Haynsworth \& Bryan, JJ., concurring \& dissenting).

On the other hand, while "white flight" was a factor which Judge Sobeloff regretted, he would not attempt to overcome it by a less stringent application of the arithmetic of racial balance. "[T] he road to integration is served neither by covert capitulation, nor by overt compromise, such as adoption of a schedule of "optimal mixing." " 429 F.2d at 827 (Sobeloff, J., concurring).

33. 418 U.S. $717(1974)$.

34. 429 F.2d at 821

35. 311 F. Supp. 265,268 (W.D.N.C. 1970), referring to an earlier opinion in the same case, 300 F. Supp. 1358,1372 (W.D.N.C. 1969). The earlier opinion indicated that Judge McMillan relied not only on the testimony of experts for this "racial mix" but also on "inferences from the Coleman Report that although mixing a few whites and a heavy majority of blacks retards the whole group, nevertheless mixing a substantial majority of whites and a few blacks helps the blacks to advance without retarding the whites." $300 \mathrm{~F}$. Supp. at 1372 . 
dents enrolled in School District No. 1 of Clarendon County, South Carolina. ${ }^{36}$ Only one white pupil enrolled for the $1973-74$ session; ${ }^{37}$ thus my fears about white flight have been realized. If the silence of the majority and the dissent of Mr. Justice Marshall in Milliken means that white flight can never be a relevant factor in considering the appropriate remedy for dismantling a dual school system, ${ }^{38}$ then Judge Sobeloff wins. But he would not be happy to know that the schools of Clarendon County are all black (save one) nor to envision with Mr. Justice Marshall the specter of all-black schools in Detroit. Certainly it would seem that Mr. Justice Marshall correctly concludes that “. . what desegregation of the public schools is all about" is ". . . to insure that Negro and white children in fact go to school together." 39 And it still seems to me that some is better than none.

Over the past eight years I have observed on my monthly visits to Richmond that it has increasingly become a black city. I said as much in Bradley $v$. School Board of City of Richmond." And I added that "the root causes of concentration of blacks in the inner cities of America are simply not known." 41 Perhaps I should have added "by judges." It is true that Dr. Karl Taeuber, a professor of sociology at the University of Wisconsin, cast most of the blame for the concentration of blacks in Richmond on discriminatory housing policies. ${ }^{42}$ But even he admitted that perhaps 15 per cent of existing segregation is attributable to income differentials, and he seemed to attach some weight to what he called "attachments to a particular neighborhood" and "an observable tendency for blacks who can afford better housing not to make, for various reasons, the long jump to a suburban homesite, but rather to move to a peripheral transitional area." ${ }_{33}$ The testimony of other social scientists-Dr. Thomas Pettigrew, Dr. Martin E. Sloane, and Dr. Jeanne C. Biggar-were not so precise. ${ }^{44}$ I share the belief of the experts that housing segregation policy

36. 429 F.2d at 820 .

37. Counsel for the school board, at my request, obtained this information concerning Clarendon School District No. I from the state superintendent of education. Letter from D.W. Robinson, Robinson \& Pope, Columbia, South Carolina, to the author, Aug. 16, 1974.

38. 418 U.S. 717 (1974).

39. Id. at 802 .

40. 462 F.2d 1058, 1066 (4th Cir. 1972), aff d by an equally divided Court. 412 U.S. 92 (1973)

41. Id.

42. Bradley v. School Bd. of City of Richmond, 338 F. Supp. 67,212 (E.D. Va. 1972).

43. 338 F. Supp. at 214. See Farley, Residential Segregation and Its Implications for School Integration, 39 LAw \& Contemp. Prob. no. 1, at 164 (1975). Professor Reynolds Farley analyzes studies of data collected by Karl and Alma Taeuber and the U.S. Census Bureau. The studies indicate that racial segregation is a far greater factor than its economic counterpart as a determinant of residential segregation patterns. Farley notes that even those blacks who can afford to move to the suburbs are highly segregated from whites in those outlying areas. Other studies indicate that the vast majority of blacks prefer integrated neighborhoods and schools. Id. at 174-77, 190. Citing discriminatory housing policies (an "institutional web of discrimination") as the prime factor, Farley concludes that economic factors do not fully explain neighborhood racial segregation patterns. Id. at 19l.

44. 338 F. Supp. at 214-15 
has been an important factor in the creation of the ghetto pattern in the American cities. But I am unwilling to jump to the conclusion that it was the only factor or even the dominant one. If it is so perfectly clear that restrictive racial covenants and discriminatory housing policies created the ghetto, whether in New York or Boston or Richmond, why is it that years after Shelley v. Kraemer ${ }^{45}$ and reported changes in such policies, the ghettos remain virtually intact?

Powell v. Texas ${ }^{46}$ is a good example of an idea whose time has not yet come. Everyone now knows something about alcoholism, and there is emerging a consensus of opinion that we ought not to put drunks in jail so long as they do not harm other persons. Even so, the Court was uneasy with the "findings of fact" below: ${ }^{47}$

(1) That chronic alcoholism is a disease which destroys the afflicted person's will power to resist the constant, excessive consumption of alcohol.

(2) That a chronic alcoholic does not appear in public by his own volition but under a compulsion symptomatic of the disease of chronic alcoholism.

(3) That Leroy Powell, defendant herein, is a chronic alcoholic who is afflicted with the disease of chronic alcoholism.

The majority was unwilling to use these "findings" as the basis for a constitutional holding that "a person may not be punished if the condition essential to constitute the defined crime is part of the pattern of his disease and is occasioned by a compulsion symptomatic of the disease." $48 \mathrm{Mr}$. Justice Marshall, writing for a plurality of the Court, thought that the Court had too little knowledge to support the announcement of an important and wide-ranging new constitutional principle. ${ }^{49}$

Just as a raconteur will seldom let the facts interfere with a good story, judges seem to have seldom allowed sociology to interfere with a good theory-until the time of the new idea has come. Sometimes it is a long time coming; but when it arrives, it is then woven into the constitutional fabric.

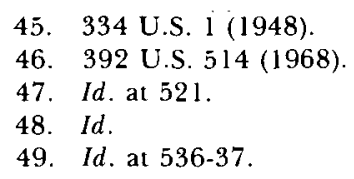

